\title{
Using Paleontology to Explore the Geography of Plants and Animals
}

\author{
Here Be Dragons: How the Study of Animal and Plant Distributions Revolutionized our \\ Views of Life and Earth, by Dennis McCarthy. Oxford University Press: Oxford, 2009. \\ pp. xxiii +214 H/b $\$ 29.95$
}

\author{
Alice B. Kehoe \\ Published online: 3 August 2010 \\ (C) Springer Science+Business Media, LLC 2010
}

In a very readable, one could even say fast-paced, text, Dennis McCarthy melds paleontology and geology to explain the geography of plants and animals. If you have not been astonished at these distributions, you will be once you get into this book. McCarthy, a research associate of the Buffalo (NY) Museum of Science, begins with the adventurous nineteenth-century naturalists Darwin, Alfred Russell Wallace, and, at the turn of that century, Alfred Wegener. Darwin and Wallace, of course, made pristine collections of both living and fossil organisms from a variety of habitats and deduced that natural selection operated on the survival of populations much as familiar agricultural breeding operated on livestock and crops. Wegener proposed that the interesting jigsaw puzzle fit of the Atlantic coasts of Africa and South America resulted from these continents drifting apart, over millions of years, from a parent landmass. Most geologists and paleontologists, convinced of the immobility of great land masses, denounced this. Wegener perished in a blizzard on the Greenland ice cap while collecting meteorological data. Decades later, with vast amounts of data on the seafloor gathered for World War II naval movements, the presence of upwelling magma along deep underwater ridges was recognized, providing the mechanism for continental drift and persuading scientists of Wegener's hypothesis.

\section{A. B. Kehoe}

Department of Anthropology,

University of Wisconsin-Milwaukee,

P.O. Box 413,

Milwaukee, WI 53201-0413, USA

A. B. Kehoe $(\square)$

3014 N. Shepard Ave,

Milwaukee, WI 53211-3436, USA

e-mail: akehoe@uwm.edu
McCarthy describes the geological history of our continents and their progenitors, Pangaea and especially Gondwana. He explains the difference between deep but narrow straits persisting for millions of years, such as that marking Wallace's Line off Australia, and wider but relatively shallow seas such as Bering Strait that periodically became land when sea levels fell. These and their reverse, the isthmuses such as Panama that rose to link continents, explain the paleontological record of relatively sudden appearances and extinctions as animals and plants crossed into previously isolated territories. Islands, both in oceans and remnant land habitats, could be golden opportunities for speciation into new nichesDarwin's famous Galápagos finches - or pressures for smaller size: pygmy mammoths and possibly pygmy hominids on the island of Flores (the recent discovery popularized as "hobbits"). Updating on Darwin's finches, by the contemporary biologists Peter and Rosemary Grant, indicates another theme: population differentiation can occur through learned behavior, not necessarily genetic changes. Galápagos finches learn their songs from their fathers, and females avoid mating with males singing a "foreign" song; when finches colonize a new location, a variant song may develop and inhibit mating with the ancestral population (p. 53). McCarthy's last two chapters discuss how biogeographical principles may illuminate human history.

Perhaps because I am an anthropologist, these chapters seem to me weaker than the preceding ones on geologic and biological data. McCarthy relies heavily on Jared Diamond in these chapters, accepting (pp. 168-72) Diamond's argument that Eurasians overcame societies in the southern hemisphere because temperate-latitude Eurasia was initially, at the end of the Pleistocene, stocked with domesticable plants and animals, and communication 
was relatively open between peoples throughout this huge landmass. It is disturbing that McCarthy repeatedly uses the word "primitive" for "beliefs" as well as "tools" of southern hemisphere people (pp. 173-174), apparently unfamiliar with the extraordinary technological and political achievements of the Inca empire Tawantinsuyo and its predecessors or that agriculture was as early in the formidable highlands of New Guinea as in the Near East (Torrence and Barton 2006). Australian evolutionary biologist Tim Flannery, not cited by McCarthy, published a powerful analysis of the biogeographical history of Australia, showing how ocean currents produce unpredictable weather likely to doom any extensive agriculture there and admiring the intelligent adaptations created by the pre-European human immigrants to that continent (Flannery 2002). Gibraltar biologist Clive Finlayson uses paleobiogeography similarly to McCarthy, emphasizing organisms' differing ability for dispersal but focusing on Pliocene-Pleistocene expansions and constrictions in ecological zones to account for extinctions of some hominid populations and the expansion of our own sapiens species (Finlayson 2009). Diamond's conventionally Eurocentric viewpoint has been regularly challenged by anthropologists (McAnany and Yoffee 2009), on factual grounds, on his acceptance of discredited hypotheses, and for its naively racist message.

McCarthy's final pages (187-191) converge human history with Darwin's Galápagos, describing how Polynesians colonized the Pacific and including the 2007 publication of the archaeological discovery of pre-Columbian Polynesian chicken bones in southern Chile (Storey et al. 2007). This is indeed a good example of biogeography illuminating history.
Reported in the prestigious Proceedings of the National Academy of Sciences, the research should finally put down the head-in-the-sand refusal of most archaeologists to look at the abundant and, in many cases, soundly supported data on pre-Columbian transoceanic contacts with the Americas (Sorenson and Johannessen 2009). The great pioneer geographer and ecologist Carl O. Sauer (1889-1975) taught his Berkeley students that biogeography was the key to scientific data on human histories. Dennis McCarthy's fascinating book is a good introduction to this approach to evolutionary biology and evolutionary anthropology. Biology teachers will find in it a wealth of lively examples and clearly developed explanations for geographical and paleontological data; McCarthy documents his sources and provides a limited but useful bibliography.

\section{References}

Torrence R, Barton H. Ancient starch research. Walnut Creek, CA: Left Coast; 2006.

Flannery T. The future eaters: an ecological history of the Australasian lands and people. New York: Grove; 2002.

Finlayson C. The humans who went extinct: why Neanderthals died out and we survived. New York: Oxford University Press; 2009.

McAnany P, Yoffee N. Questioning collapse: human resilience, ecological vulnerability, and the aftermath of empire. New York: Cambridge University Press; 2009.

Storey A, Ramirez J, Quiroz D, Burley D, Addison D, Walter R, et al. Radiocarbon and DNA evidence for Pre-Columbian introduction of Polynesian chickens in Chile. Proc Nat Acad Sci. 2007;104 (25):10335-9.

Sorenson J, Johannessen C. World trade and biological exchanges before 1492. Bloomington: iUniverse.com; 2009. 